\title{
PENGARUH KONSELING MODIFIKASI GAYA HIDUP TERHADAP ASUPAN SERAT, KADAR GLUKOSA DARAH PUASA, DAN KADAR INTERLEUKIN 18 (IL-18) PADA REMAJA OBESITAS DENGAN SINDROM METABOLIK
}

\author{
Nur Shofia, M. Sulchan*) \\ Program Studi Ilmu Gizi Fakultas Kedokteran Universitas Diponegoro \\ Jl.Dr.Sutomo No.18, Semarang, Telp (024) 8453708, Email : gizifk@ undip.ac.id
}

\begin{abstract}
Background: Obesity in adolescents plays role in the development of metabolic syndrome (MetS). Elevated levels of the fasting blood glucose $(F B G)$ and interleukin 18 (IL-18) are being considered as MetS risk factors. Diet and physical activity are effective strategy to manage the risk of MetS.

Method: Twenty seven obese adolescents with MetS were participated in lifestyle modification counseling. Sixteen adolescents got counseling for once and eleven adolescents followed intensive counseling for two months. Diet, physical activity, FBG levels, and IL-18 levels were assessed before and after the program. The FBG levels was measured using automatic method with ABX pentra 400 tool and the levels of IL-18 was analyzed by enzyme-linked immunosorbent assay (ELISA).

Result: The counseling resulted significant improvements to the diet quality, physical activity, and the levels of IL-18, but not to fiber intake and FBG levels. Intensive counseling group showed significant differences in the diet quality and the IL-18 levels, $p=0.006$ and $p=0.006$ respectively, whereas in the non-intensive group counseling showed significant differences in the diet quality, physical activity, and the IL-18 levels, $p=0.040 ; p=0.001 ; p=0.002$, on sequence. Mean changes of diet quality was higher in the intensive counseling group $(1.09 \pm 1.04)$ compared with the counterpart $(0.81 \pm 1.47)$. However, physical activity was higher in the non-intensive counseling group compared with intensive counseling group, $1089.47 \pm 1373.68$ and $179.409 \pm 524.151$, respectively. Decreased levels of IL-18 was also higher in the non-intensive counseling group compared with the intensive counseling group, $210.60 \pm 217.97$ and $175.98 \pm 167.98$, on sequence.

Conclusion: Counseling proven to modify lifestyle in the form of improved quality of diet, physical activity, and decrease levels of IL-18, but not proven to increase fiber intake and reduce levels of FBG. Lifestyle modification counseling conducted intensively shown to further improve the quality of diet, but not shown to further increase physical activity and levels of IL-18.
\end{abstract}

Keyword: metabolic syndrome, lifestyle modification counseling, fiber, fasting blood glucose, IL-18.

\section{ABSTRAK}

Latar Belakang: Obesitas pada remaja berperan dalam perkembangan sindrom metabolik (SM). Peningkatan kadar glukosa darah puasa $(G D P)$ dan interleukin 18 (IL-18) merupakan faktor risiko terjadinya SM. Pengaturan diet dan aktivitas fisik adalah cara efektif untuk menurunkan risiko SM.

Metode: Dua puluh tujuh remaja obesitas dengan SM mengikuti konseling modifikasi gaya hidup. Enam belas remaja mendapat satu kali konseling dan sebelas remaja mengikuti konseling intensif selama dua bulan. Asupan, aktivitas fisik, kadar GDP, dan kadar IL-18 diukur sebelum dan sesudah intervensi. Kadar GDP diukur menggunakan metode automatic dengan alat ABX pentra 400 dan kadar IL-18 dianalisis dengan metode enzyme-linked immunosorbent assay (ELISA).

Hasil: Terdapat peningkatan bermakna pada kualitas diet dan aktivitas fisik serta penurunan bermakna pada kadar IL-18, tetapi tidak pada asupan serat dan kadar GDP, setelah konseling modifikasi gaya hidup. Kelompok konseling intensif, menunjukkan perbedaan bermakna pada kualitas diet $(p=0,006)$ dan kadar IL-18 $(p=0,006)$, sedangkan perbedaan bermakna pada kelompok konseling tidak intensif adalah pada kualitas diet ( $p=0,040)$, aktivitas fisik $p=0,001)$, dan kadar IL-18 ( $p=0,002)$. Peningkatan kualitas diet lebih tinggi pada kelompok konseling intensif $(1,09 \pm 1,04)$ dibandingkan kelompok konseling tidak intensif $(0,81 \pm 1,47)$. Namun, peningkatan aktivitas fisik lebih tinggi pada kelompok konseling tidak intensif $(1089,47 \pm 1373,68)$ dibandingkan kelompok konseling intensif $(179,409 \pm 524,151)$. Penurunan kadar IL-18 juga lebih tinggi pada kelompok konseling tidak intensif $(210,60 \pm 217,97)$ dibandingkan kelompok konseling intensif $(175,98 \pm 167,98)$.

Simpulan: Konseling terbukti memodifikasi gaya hidup berupa peningkatan kualitas diet, aktivitas fisik, dan penurunan kadar IL-18, tetapi tidak terbukti meningkatkan asupan serat dan menurunkan kadar GDP. Konseling modifikasi gaya hidup secara intensif terbukti lebih meningkatkan kualitas diet dibandingkan kelompok konseling tidak intensif, tetapi tidak terbukti lebih meningkatkan aktivitas fisik dan kadar IL-18.

Kata kunci: sindrom metabolik, konseling modifikasi gaya hidup, serat, glukosa darah puasa, IL-18. 


\section{PENDAHULUAN}

Obesitas merupakan masalah global. Tingginya prevalensi obesitas tidak lagi hanya dialami oleh negara maju, tetapi juga negara berkembang. ${ }^{1}$ Penelitian oleh National Health and Nutrition Examination Survei (NHANES) menunjukkan prevalensi obesitas di Amerika Serikat tahun 2011-2012 pada orang dewasa usia $\geq 20$ tahun adalah $34.9 \%$ serta anak dan remaja usia 2-19 tahun adalah $16.9 \% .^{2} \mathrm{Di}$ Indonesia, data Riskesdas tahun 2013 menunjukkan prevalensi obesitas penduduk usia $>18$ tahun adalah $15.4 \%$ dan pada usia 16-18 tahun adalah $1.6 \% .^{3}$

Penelitian pendahuluan yang dilakukan di SMA Negeri 2 Semarang pada tahun 2014 memperoleh hasil bahwa dari 835 siswa yang diskrining, 9,6\% siswa mengalami overweight, $7,9 \%$ siswa mengalami obesitas, dan $7,3 \%$ siswa mengalami obesitas sentral. ${ }^{4}$ Obesitas inilah yang meningkatkan risiko terjadinya sindrom metabolik. Hal ini disebabkan karena pada penderita obesitas umumnya terjadi gangguan metabolisme glukosa, peningkatan tekanan darah, dan dislipidemia. ${ }^{5}$

Obesitas yang berhubungan dengan sindrom metabolik salah satunya dicirikan dengan terjadinya hiperglikemi. ${ }^{6}$ Hiperglikemi akibat resistensi insulin dapat menjadi risiko terjadinya penyakit diabetes mellitus tipe dua. ${ }^{7}$ Data Riskesdas tahun 2013 menunjukkan bahwa 6.9\% penduduk Indonesia usia $\geq 15$ tahun mengalami gangguan glukosa darah puasa. ${ }^{3}$ Jika glukosa darah puasa terganggu, maka individu tersebut memiliki risiko terkena diabetes mellitus. ${ }^{8}$

Selain meningkatkan risiko penyakit kronis, obesitas dan sindrom metabolik juga meningkatkan risiko terjadinya inflamasi kronis. ${ }^{9}$ Penelitian cross-sectional yang dilakukan di India tahun 2010 menunjukkan bahwa peningkatan jumlah adiposa di dalam tubuh berkaitan dengan peningkatan plasma sitokin proinflamasi, terutama pada individu overweight dan obesitas dibandingkan dengan individu sehat (berat badan normal). ${ }^{10}$ Beberapa penelitian juga menyebutkan bahwa diabetes mellitus dan sindrom metabolik lain adalah faktor yang mendasari timbulnya inflamasi kronik pada seseorang. ${ }^{9}$

Interleukin 18 (IL-18) merupakan salah satu sitokin proinflamasi yang nilainya meningkat seiring timbulnya inflamasi pada penyakit kronis. ${ }^{9}$ Penelitian pendahuluan di SMA Negeri 2 Semarang memperoleh hasil bahwa dari 47 siswa yang mengalami obesitas sentral, seluruhnya memiliki nilai IL-18 melebihi batas normal. ${ }^{4}$ Nilai ini dapat menjadi dasar untuk memprediksi diabetes mellitus tipe dua dan CVD pada seseorang. Oleh karena itu, peningkatan nilai IL-18 pada seseorang dapat dijadikan sebagai prediktor perkembangan penyakit kronis. ${ }^{9}$

Selain gangguan glukosa darah puasa dan IL-18, asupan serat juga memiliki hubungan dengan obesitas. Penelitian menyebutkan bahwa populasi yang mengonsumsi asupan tinggi serat akan memiliki prevalensi obesitas yang rendah. ${ }^{11}$ Penelitian juga menunjukkan bahwa konsumsi makanan tinggi serat akan berpengaruh pada penurunan kadar glukosa darah puasa dan kadar IL$18 . .^{12,13}$

Diagnosis dini adanya sindrom metabolik disertai perubahan atau modifikasi gaya hidup akan menurunkan risiko terjadinya penyakit kronis. Modifikasi gaya hidup yang menggabungkan pengaturan asupan dan aktivitas fisik terbukti dapat menurunkan berat badan penderita obesitas dan gangguan yang menyertainya. ${ }^{14}$ Penelitian terhadap anak usia 9-10 tahun membuktikan bahwa aktivitas fisik 3 kali per minggu (45 menit/hari) dan konseling diet (dua minggu sekali) selama 8 minggu dapat menurunkan indeks massa tubuh dan profil lipid. ${ }^{15}$ Dengan demikian, penurunan dan menejemen berat badan serta aktivitas fisik akan memperbaiki tubuh dari gangguan metabolik. ${ }^{16}$

\section{METODE}

Rancangan penelitian ini adalah nonrandomized pre-post test control group design dengan ruang lingkup gizi masyarakat. Variabel bebas adalah konseling modifikasi gaya hidup, sedangkan variabel terikatnya adalah kualitas diet, aktivitas fisik, asupan serat, kadar glukosa darah puasa, dan kadar IL-18.

Subjek penelitian adalah siswa obesitas dengan sindrom metabolik di SMA 2 Semarang. Kriteria inklusi adalah lain remaja usia 15-18 tahun dengan IMT $>24,99 \mathrm{~kg} / \mathrm{m}^{2}$ dan berada pada persentil $\geq 95$ dari grafik persentil IMT untuk umur 2-20 tahun, obesitas sentral dengan lingkar pinggang pada laki-laki laki-laki $\geq 93 \mathrm{~cm}$ dan pada perempuan $\geq 87 \mathrm{~cm}$, bersedia menjadi subjek penelitian dengan mengisi inform consent, dan tidak sedang mengonsumsi obat-obatan untuk obesitas, hipertensi, dan hipoglikemia, sedangkan kriteria eksklusi antara lain mengundurkan diri sebagai subjek penelitian dan meninggal dunia saat penelitian berlangsung.

Subjek penelitian berasal dari penelitian pendahuluan yang berjumlah 47 orang. Namun, hanya 38 subjek yang bersedia mengikuti penelitian lanjutan. Penelitian diawali dengan memberikan 
konseling dan sebuah booklet kepada 38 subjek. Materi yang disampaikan pada konseling adalah mekanisme dan akibat dari sindrom metabolik serta cara memodifikasi gaya hidup. Booklet berisi delapan materi yaitu, cara membaca hasil laboratorium, penjelasan tentang obesitas dan hubungannya dengan sindrom metabolik, cara pengelolaan berat badan, pola makan seimbang/PUGS, cara membaca label makanan, cara pemilihan makanan di luar rumah, sedentary lifestyle, dan aktivitas fisik. Setelah konseling tersebut dilakukan, subjek penelitian terbagi menjadi dua kelompok, yaitu kelompok konseling tidak intensif dan konseling intensif. Subjek pada masing-masing kelompok tidak ditentukan oleh peneliti, melainkan terseleksi dengan sendirinya atas kehendak subjek mau menjadi bagian dari kelompok konseling tidak intensif atau kelompok konseling intensif. Subjek pada kelompok konseling tidak intensif hanya diberikan satu kali konseling pada awal penelitian, sedangkan subjek pada kelompok konseling intensif diberikan pendampingan dan konseling setiap minggu sebanyak 1-8 kali selama 2 bulan (SeptemberNovember 2014). Jumlah konseling pada masingmasing subjek bervariasi disesuaikan dengan waktu luang subjek bertemu peneliti. Materi yang disampaikan saat konseling adalah materi yang ada di dalam booklet. Pada akhir penelitian, dari 38 subjek tersebut, hanya 27 orang subjek yang bersedia mengikuti pengukuran data akhir, 11 orang dari kelompok konseling intensif dan 16 orang dari kelompok konseling tidak intensif.

Pengukuran data subjek berupa antropometri, riwayat asupan makan, aktivitas fisik, kadar glukosa darah puasa (GDP), dan kadar interleukin 18 (IL-18) dilakukan sebelum dan setelah intervensi. Asupan diukur dengan menggunakan semiquantitative food frequency questionnaire yang kemudian dikonversikan ke dalam satuan gram/hari dan dianalisis dengan software nutrisi makanan. Asupan yang diukur berupa asupan serat (gram/hari) dan kualitas diet (skor). Skor kualitas diet ditentukan berdasarkan modifikasi dari diet quality index (DQI). Kualitas diet ini terdiri dari asupan natrium, kolesterol, serat, lemak total, dan densitas energi. Asupan natrium baik bila $<2300 \mathrm{mg} /$ hari, asupan kolesterol baik bila $<300 \mathrm{mg} /$ hari, asupan serat baik bila $\geq 30 \mathrm{~g} / \mathrm{hari}$ untuk perempuan dan $\geq 37$ g/hari untuk laki-laki, asupan lemak baik bila $<30 \%$ dari total asupan/hari, dan densitas energi baik bila berada pada angka 1,45-1,98 untuk perempuan dan 1,53-2,08 untuk laki-laki. Asupan baik diberi skor 2, dan asupan tidak baik diberi skor 1. Skor kualitas diet tergolong baik jika berada di atas median. Aktivitas fisik diukur menggunakan international physical activity questionnaire (IPAQ). Kadar glukosa darah puasa diukur menggunakan metode automatic dengan menggunakan alat $\mathrm{ABX}$ pentra 400, sedangkan kadar IL-18 dianalisis dengan metode enzymelinked immunosorbent assay (ELISA).

Pengolahan dan analisis data digunakan program statistik. Analisis deskriptif dilakukan untuk mendeskripsikan karakteristik subjek. Normalitas data diuji dengan Saphiro Wilk. Perbedaan kualitas diet, asupan serat, aktivitas fisik (nilai METs), kadar glukosa darah puasa, dan kadar interleukin 18 sebelum dan setelah intervensi dianalisis dengan pair t-test dan Wilcoxon, sedangkan perbedaan pengaruh intervensi kepada kelompok konseling intensif dan tidak intensif dianalisis menggunakan independent t-test dan Mann Whitney.

\section{HASIL PENELITIAN}

Penelitian ini menunjukkan bahwa konseling selama dua bulan terbukti memodifikasi gaya hidup. Tabel 1 menunjukkan adanya peningkatan kualitas diet, aktivitas fisik, dan asupan serat setelah dilakukan konseling. Akan tetapi, perbedaan bermakna hanya ditemukan pada kualitas diet dan aktivitas fisik, sedangkan asupan serat tidak menunjukkan perbedaan yang bermakna. Rerata kadar GDP subjek meningkat dibandingkan sebelum konseling, sedangkan rerata kadar IL-18 subjek menurun setelah diberikan konseling. Dibandingkan dengan sebelum konseling, setelah konseling terdapat peningkatan persentase subjek dengan kadar GDP melebihi normal, yaitu dari 0\% menjadi $7,4 \%$. Namun, terjadi penurunan persentase subjek dengan kadar IL-18 melebihi normal, yaitu dari $100 \%$ menjadi $66,7 \%$.

Tabel 1. Perubahan Nilai Kualitas Diet, Aktivitas Fisik, Asupan Serat, Kadar GDP, Kadar IL-18

\begin{tabular}{lccc}
\hline Komponen & Awal $(\mathbf{n}=\mathbf{2 7})$ & Akhir $(\mathbf{n}=\mathbf{2 7})$ & Sig. $(\mathbf{p})$ \\
\hline Kualitas Diet & $6,33 \pm 1,07$ & $7,26 \pm 0,76$ & $0,002^{*}$ \\
Aktivitas Fisik & $1401,27 \pm 1333,74$ & $2119,98 \pm 1768,08$ & $0,001^{*}$ \\
$\quad$ MET-menit/minggu) & & & \\
Asupan Serat (g/hari) & $11,59 \pm 7,43$ & $11,83 \pm 3,70$ & 0,581 \\
$\quad<30$ gram / <37 gram & $27(100 \%)$ & $27(100 \%)$ & \\
\hline
\end{tabular}


*Bermakna

\begin{tabular}{cccc}
\hline Kadar GDP $(\mathrm{mg} / \mathrm{dL})$ & $82,26 \pm 8,37$ & $84,67 \pm 14,00$ & 0,895 \\
$\geq 110 \mathrm{mg} / \mathrm{dL}$ & $0(0 \%)$ & $2(7,4 \%)$ & \\
Kadar IL-18 $(\mathrm{pg} / \mathrm{mL})$ & $405,53 \pm 132,57$ & $209,03 \pm 195,98$ & $0,000^{*}$ \\
$\geq 120 \mathrm{pg} / \mathrm{mL}$ & $27(100 \%)$ & $16(66,7 \%)$ & \\
\hline
\end{tabular}

Pada tingkat intensitas konseling, jumlah pertemuan untuk melakukan konseling berbeda-

beda, sesuai waktu luang subjek bertemu peneliti.

Tingkat intensitas tersebut disajikan pada tabel 2.

Tabel 2. Tingkat Intensitas Konseling

\begin{tabular}{lcll}
\hline \multicolumn{2}{c}{ Frekuensi Pendampingan dan Konseling (kali) } & n & \% \\
\hline \multirow{2}{*}{ Konseling Intensif } & $5-8$ & 3 & 11,11 \\
Konseling Tidak Intensif & $1-4$ & 8 & 29,63 \\
\hline
\end{tabular}

Subjek penelitian berjumlah 27 orang, terdiri dari 19 laki-laki dan 8 perempuan. Subjek pada kelompok konseling intensif terdiri dari 5 orang laki-laki $(45,5 \%)$ dan 6 orang perempuan $(54,5 \%)$, sedangkan pada kelompok konseling tidak intensif terdiri dari 14 orang laki-laki $(87,5 \%)$ dan 2 orang perempuan $(12,5 \%)$. Subjek termuda berusia 16 tahun dan subjek termuda berusia 18 tahun. Median usia dari kelompok konseling intensif adalah 16 tahun, sedangkan pada kelompok konseling tidak intensif adalah 17 tahun. Umur dan jenis kelamin subjek disajikan dalam tabel 3.

Tabel 3. Umur dan Jenis Kelamin Subjek pada Kelompok Konseling Intensif dan Tidak Intensif

\begin{tabular}{lcc}
\hline Variabel & Konseling Intensif $(\mathbf{n = 1 1})$ & $\begin{array}{c}\text { Konseling Tidak Intensif } \\
(\mathbf{n = 1 6})\end{array}$ \\
\hline Umur & $16^{\mathrm{a}}(16-18)$ & $17^{\mathrm{a}}(16-18)$ \\
Jenis Kelamin & & \\
Laki-laki & $5(45,5 \%)$ & $14(87,5 \%)$ \\
Perempuan & $6(54,5 \%)$ & $2(12,5 \%)$ \\
\hline
\end{tabular}

Median

\section{Perbedaan pada Kelompok Konseling Intensif dan Tidak Intensif}

Tabel 4. Perbedaan Kualitas Diet, Aktivitas Fisik, Asupan Serat, Kadar GDP, Kadar IL-18 Sebelum Intervensi pada Kelompok

\begin{tabular}{lccc}
\hline Variabel & \multicolumn{2}{c}{ Rerata \pm SD } & Sig. $(\boldsymbol{p})$ \\
\cline { 2 - 4 } & Konseling Intensif & Konseling Tidak Intensif & \\
Kualitas Diet & $6,09 \pm 0,94$ & $6,50 \pm 1,16$ & 0,341 \\
Aktivitas Fisik (MET- & $1626,64 \pm 1497,70$ & $1246,34 \pm 1234,96$ & 0,490 \\
mnt / minggu) & & & \\
Asupan Serat (g/hari) & $13,40 \pm 8,29$ & $10,34 \pm 6,77$ & 0,152 \\
Kadar GDP (mg/dL) & $81,91 \pm 8,57$ & $82,50 \pm 8,50$ & 0,861 \\
Kadar IL-18 (pg/ mL) & $359,66 \pm 114,06$ & $437,07 \pm 138,51$ & 0,139 \\
\hline
\end{tabular}

Berdasarkan tabel 4, diperoleh bahwa

Disimpulkan bahwa lima variabel pada kelompok konseling intensif dan kelompok konseling tidak kualitas diet, aktivitas fisik, asupan serat, kadar GDP, dan kadar IL-18 kedua kelompok sebelum intervensi menunjukkan tidak ada perbedaan. intensif tersebut bersifat homogen atau tidak berbeda.

Tabel 5. Perbedaan Kualitas Diet, Aktivitas Fisik, Asupan Serat, Kadar GDP, Kadar IL-18 Sebelum dan Sesudah Intervensi pada Kelompok Konseling Intensif dan Tidak Intensif

\begin{tabular}{|c|c|c|c|c|c|c|}
\hline \multirow[t]{2}{*}{ Variabel } & \multicolumn{3}{|c|}{ Konseling Intensif } & \multicolumn{3}{|c|}{ Konseling Tidak Intensif } \\
\hline & \multicolumn{2}{|c|}{ Rerata \pm SD } & \multirow[t]{2}{*}{ Sig. $(p)$} & \multicolumn{2}{|c|}{ Rerata \pm SD } & Sig. $(p)$ \\
\hline & Awal & Akhir & & Awal & Akhir & \\
\hline Kualitas Diet & $6,09 \pm 0,94$ & $\begin{array}{c}7,18 \pm \\
0,87\end{array}$ & $0,006^{*}$ & $\begin{array}{l}6,50 \pm \\
1,16\end{array}$ & $7,31 \pm 0,7$ & $0,040 *$ \\
\hline
\end{tabular}




\begin{tabular}{lccllll}
\hline Aktivitas & $1626,64 \pm$ & $1806,05 \pm$ & 0,283 & $1246,34 \pm$ & $2335,81 \pm$ & $0,001^{*}$ \\
Fisik (MET- & 1497,70 & 1294,01 & & 1234,96 & 2044,58 & \\
mnt / minggu) & & & & & & \\
Asupan Serat & $13,40 \pm 8,29$ & $11,68 \pm$ & 0,523 & $10,34 \pm$ & $11,94 \pm 3,88$ & 0,339 \\
(g/hari) & & 3,61 & & 6,77 & & \\
Kadar GDP & $81,91 \pm 8,57$ & $82,73 \pm$ & 0,859 & $82,50 \pm$ & $86,00 \pm 15,82$ & 0,717 \\
(mg/dL) & & 11,29 & & 8,50 & & \\
Kadar IL-18 & $359,66 \pm 114,06$ & $183,68 \pm$ & $0,006^{*}$ & $437,07 \pm$ & $226,47 \pm$ & $0,002^{*}$ \\
(pg/mL) & & 93,11 & & 138,51 & 156,01 & \\
\hline
\end{tabular}

*Bermakna

Berdasarkan tabel 5, diketahui bahwa terdapat perbedaan pada kualitas diet dan kadar IL18 sebelum dan sesudah intervensi pada kelompok konseling intensif dan kelompok konseling tidak intensif. Namun, tidak terdapat perbedaan asupan serat dan kadar GDP sebelum dan sesudah intervensi pada kelompok konseling intensif dan kelompok konseling tidak intensif. Pada variabel aktivitas fisik, terdapat perbedaan pada kelompok konseling tidak intensif, tetapi tidak terdapat perbedaan pada kelompok konseling intensif.

Tabel 6. Perbedaan Perubahan Rerata Kualitas Diet, Aktivitas Fisik, Asupan Serat, Kadar GDP, Kadar IL18 Sebelum dan Sesudah Intervensi pada Kelompok Konseling Intensif dan Tidak Intensif

\begin{tabular}{lccc}
\hline Variabel & \multicolumn{2}{c}{ Rerata \pm SD } & Sig. $(\boldsymbol{p})$ \\
\cline { 2 - 4 } & Konseling Intensif & $\begin{array}{c}\text { Konseling Tidak } \\
\text { Intensif }\end{array}$ \\
$\Delta$ Kualitas Diet & $1,09 \pm 1,04$ & $0,81 \pm 1,47$ & 0,594 \\
$\Delta$ Aktivitas Fisik (MET- & $179,41 \pm 524,15$ & $1089,48 \pm 1373,68$ & 0,139 \\
menit / minggu) & & & \\
$\Delta$ Asupan Serat (g/hari) & $-1,73 \pm 8,65$ & $1,59 \pm 8,37$ & 0,327 \\
$\Delta$ Kadar GDP (mg/dL) & $0,82 \pm 14,69$ & $3,50 \pm 15,80$ & 0,660 \\
$\Delta$ Kadar IL-18 (pg/ mL) & $-175,98 \pm 167,98$ & $-210,60 \pm 217,97$ & 0,662 \\
\hline
\end{tabular}

Berdasarkan tabel 7, diperoleh hasil bahwa perubahan rerata kualitas diet, aktivitas fisik, asupan serat, kadar GDP, dan kadar IL-18 antara kelompok konseling intensif dan kelompok konseling tidak intensif tidak memiliki perbedaan yang bermakna. Rerata skor kualitas diet kelompok konseling intensif meningkat dari 6,09 menjadi 7,18 ( $\Delta=$ 1,09 ), dan kelompok tidak intensif meningkat dari 6,50 menjadi 7,31 $(\Delta=0,81)$. Aktivitas fisik kelompok konseling intensif meningkat dari 1626,64 METs menjadi 1806,05 METs $(\Delta=179,41)$, dan kelompok konseling tidak intensif juga meningkat dari 1246,34 METs menjadi 2335,81 METs $(\Delta=1089,48)$. Asupan serat pada kelompok konseling intensif menurun dari 13,40 gram menjadi 11,68 gram $(\Delta=-1,73)$, sedangkan pada kelompok konseling tidak intensif meningkat dari 10,34 gram menjadi 11,94 gram $(\Delta=1,59)$. Kadar glukosa darah puasa kelompok konseling intensif meningkat dari $81,91 \mathrm{mg} / \mathrm{dL}$ menjadi $82,73 \mathrm{mg} / \mathrm{dL}$ $(\Delta=0,82)$, dan kelompok konseling tidak intensif meningkat dari $82,50 \mathrm{mg} / \mathrm{dL}$ menjadi $86,00 \mathrm{mg} / \mathrm{dL}$ $(\Delta=3,50)$. Rerata kadar IL-18 pada kelompok konseling intensif menurun dari $359,66 \mathrm{pg} / \mathrm{mL}$ menjadi $183,68 \mathrm{pg} / \mathrm{mL}(\Delta=175,98)$, dan kelompok tidak intensif juga menurun dari 437,06 pg/mL menjadi $226,47 \mathrm{pg} / \mathrm{mL}(\Delta=210,60)$.

\section{PEMBAHASAN}

Subjek penelitian pada kelompok konseling intensif dan tidak intensif memiliki perbandingan jumlah remaja perempuan dan laki-laki yang berbeda. Kelompok konseling intensif memiliki jumlah remaja perempuan yang lebih banyak dibandingkan jumlah laki-laki, sedangkan kelompok konseling tidak intensif memiliki jumlah remaja laki-laki lebih banyak dibandingkan jumlah perempuan. Subjek pada setiap kelompok tidak ditentukan oleh peneliti, sehingga mempengaruhi jumlah dan jenis kelamin pada masing-masing kelompok.

Jumlah remaja perempuan pada kelompok konseling intensif lebih banyak dibanding jumlah laki-laki. Hal ini dipengaruhi oleh body image atau persepsi tubuh. Remaja putri umumnya lebih memperhatikan bentuk tubuh untuk menjadi tinggi dan langsing. ${ }^{17}$ Melalui konseling secara intensif, remaja putri dibimbing untuk mengatur diet dan aktivitas fisik yang benar sehingga risiko sindrom metabolik dapat menurun. ${ }^{18}$ 
Perbedaan kualitas diet sebelum dan sesudah intervensi pada kelompok konseling intensif dan kelompok konseling tidak intensif diperoleh bermakna. Kualitas diet ini diukur berdasarkan kepatuhan subjek terhadap rekomendasi diet yang diberikan. ${ }^{19}$ Berdasarkan analisis perbedaan perubahan rerata kualitas diet, diperoleh tidak ada perbedaan bermakna antara kelompok konseling intensif dan kelompok konseling tidak intensif. Namun, kenaikan skor kualitas diet pada kelompok konseling intensif lebih tinggi dibanding kelompok konseling tidak intensif. Hal ini disebabkan karena kelompok konseling intensif memperoleh konseling berulang-ulang disertai pendampingan, sedangkan kelompok konseling tidak intensif hanya memperoleh satu kali konseling. Pernyataan ini didukung dengan penelitian yang menyebutkan bahwa konseling gizi berperan penting terhadap kepatuhan diet. Pada konseling gizi, terjadi pendekatan personal yang berguna untuk membantu individu memperoleh pengertian yang lebih baik mengenai permasalahan gizi yang dihadapi dan membantu untuk mengambil keputusan dalam mengatasi masalah gizi tersebut. Dalam hal ini, subjek dimotivasi untuk melakukan perubahan perilaku, termasuk dalam perubahan kualitas diet. ${ }^{20}$

Aktivitas fisik pada kelompok konseling intensif dan tidak intensif mengalami peningkatan (dilihat dari nilai METs). METs adalah satuan dari aktivitas fisik, yaitu akumulasi waktu dalam satu minggu untuk melakukan aktivitas fisik (menit/minggu). Berdasarkan analisis, perbedaan bermakna antara sebelum dan sesudah intervensi ditemukan pada kelompok konseling tidak intensif, tetapi tidak pada kelompok konseling intensif.

Aktivitas fisik kelompok konseling tidak intensif awalnya tergolong rendah. Setelah dua bulan, aktivitas fisik kelompok ini meningkat menjadi sedang. Pada kelompok konseling intensif, kategori aktivitas fisik sebelum dan sesudah intervensi tetap tergolong sedang. Perbedaan ini dapat dipengaruhi oleh faktor luar yang tidak bisa dikendalikan oleh peneliti, yaitu motivasi. Diketahui bahwa, kelompok konseling intensif dan tidak intensif awalnya mendapat konseling dan booklet. Oleh sebab itu, walaupun kelompok konseling tidak intensif tidak memperoleh pendampingan, tetapi kelompok ini juga mendapat perlakuan untuk meningkatkan pengetahuan serta motivasi agar melakukan perubahan gaya hidup. ${ }^{21}$ Selain itu, jumlah laki-laki (14 orang) pada kelompok konseling tidak intensif lebih banyak dibandingkan jumlah perempuan (2 orang).
Aktivitas fisik remaja laki-laki umumnya lebih tinggi dibandingkan remaja perempuan sehingga aktivitas fisik pada kelompok konseling tidak intensif lebih tinggi dibandingkan kelompok konseling intensif. Remaja laki-laki cenderung lebih menyukai olahraga dan kegiatan lapangan dibandingkan remaja wanita, seperti bermain sepak bola, basket, futsal, dan kegiatan lain sehingga hal ini mempengaruhi nilai aktivitas fisik kelompok tersebut. $^{22}$

Selanjutnya, ditemukan bahwa tidak terdapat perbedaan yang bermakna pada asupan serat sebelum dan sesudah intervensi pada kelompok konseling intensif dan kelompok konseling tidak intensif. Meskipun asupan serat kelompok konseling tidak intensif meningkat dan pada kelompok konseling intensif menurun, tetapi perbedaan perubahan rerata antara kedua kelompok tersebut tidak bermakna.

Asupan serat sebelum dan sesudah intervensi pada kelompok konseling intensif dan kelompok konseling tidak intensif tersebut masih tergolong kurang. Berdasarkan AKG 2013, asupan serat bagi usia 16-18 tahun adalah $\geq 37$ gram untuk laki-laki dan $\geq 30$ gram/hari untuk wanita. Rendahnya asupan serat dapat disebabkan oleh berbagai faktor. Salah satu penyebab asupan serat rendah adalah karena para remaja tidak terbiasa mengonsumsi sumber makanan tinggi serat. Selain itu, ketidaksukaan remaja terhadap sayur dan buah juga berdampak pada rendahnya asupan serat. ${ }^{23}$ Penelitian tahun 2007 terhadap remaja usia 11-14 tahun di Texas menunjukkan bahwa tingkat kesukaan terhadap buah dan sayur menjadi faktor yang berpengaruh dalam konsumsi serat. $^{24}$ Preferensi remaja masa kini cenderung lebih menyukai makanan rendah serat dan tinggi lemak. Jika terus berlanjut, perilaku ini akan menetap hingga usia dewasa dan bisa berdampak buruk pada kesehatannya di masa depan. Rendah atau tingginya asupan serat juga dipengaruhi oleh ketersediaan sumber makanan itu sendiri. Hal ini disebabkan karena makanan yang disediakan di rumah dan kantin sekolah cenderung tinggi energi tetapi rendah serat. ${ }^{23}$ Ketersediaan sumber makanan berserat di rumah bergantung pada perilaku orang tua. Contoh dan dukungan orang tua akan mempengaruhi konsumsi buah dan sayur pada anak remajanya. Orang tua yang suka mengonsumsi makanan rendah serat cenderung akan menyediakan makanan yang rendah serat pula. ${ }^{25}$ Penelitian yang dilakukan di pada tahun 2010 terhadap remaja Afrika dan Amerika usia 10-14 tahun menunjukkan bahwa ketersediaan buah dan sayur di rumah berhubungan 
positif dengan jumlah konsumsi buah dan sayur pada remaja. ${ }^{26}$

Pada kadar glukosa darah puasa (GDP), baik pada kelompok intensif maupun tidak intensif menunjukkan tidak ada perbedaan sebelum dan sesudah intervensi. Perubahan rerata juga tidak menunjukkan perbedaan yang bermakna antara kelompok konseling intensif dan kelompok konseling tidak intensif. Peningkatan kadar glukosa darah puasa merupakan langkah pertama dari perkembangan diabetes mellitus tipe dua. Data post penelitian ini menunjukkan bahwa 7,4\% subjek memiliki kadar glukosa darah puasa melebihi normal. Kemungkinan subjek menyangkal tidak berpuasa sebelum tes darah tidak dapat sepenuhnya dikesampingkan karena dapat menyebabkan peningkatan rerata dari glukosa darah puasa pada penelitian ini. Peningkatan ini juga dapat dipengaruhi oleh status obesitas yang dimiliki para subjek. Penelitian menunjukkan bahwa status obesitas memiliki hubungan bermakna dengan gangguan glukosa darah puasa. ${ }^{25}$ Subjek penelitian ini masih berada pada kondisi obesitas sentral, dimana distribusi penyimpanan lemak lebih banyak di bagian viseral. Lemak viseral mempengaruhi terjadinya peningkatan kadar glukosa darah puasa karena pada jaringan lemak viseral terdapat hormone sentitive lipase (HSL) yang memecah trigliserida menjadi asam lemak bebas dan gliserol. Peningkatan asam lemak bebas ini akan menghambat ambilan glukosa dari jaringan perifer sehingga meningkatkan hiperglikemi. ${ }^{28}$ Penumpukan lemak viseral juga akan meningkatkan jumlah asam lemak bebas dari hasil lipolisis yang berpengaruh pada sensitifitas reseptor insulin. ${ }^{29}$ Selain itu, kadar glukosa darah puasa ini juga dapat dipengaruhi oleh masih rendahnya asupan serat subjek, baik pada kelompok konseling intensif maupun tidak intensif. Padahal, serat dapat membantu untuk menurunkan kadar glukosa darah. Serat dalam usus besar akan difermentasi oleh bakteri anaerob demi menghasilkan asam lemak rantai pendek jenis propionat yang dapat mengurangi proses glukoneogenesis. Hal ini berpengaruh terhadap peningkatan sekresi insulin dan pemakaian glukosa oleh sel hati. ${ }^{12}$

Kadar IL-18 sebelum dan sesudah intervensi pada kelompok konseling intensif dan kelompok konseling tidak intensif memiliki perbedaan yang bermakna. Rerata kadar IL-18 kedua kelompok menurun. Namun, analisis perbedaan perubahan rerata menunjukkan tidak ada perbedaan antara kedua kelompok. Penurunan kadar IL-18 ini dapat dipengaruhi oleh peningkatan aktivitas fisik dan kualitas diet. Asupan tinggi lemak dan kolesterol serta rendah serat dapat meningkatkan kadar IL-18. ${ }^{13}$ Ditinjau dari perubahan kualitas diet, kedua kelompok mengalami peningkatan kualitas diet, terutama ditandai dengan penurunan asupan lemak total dan kolesterol. Penurunan kadar IL-18 kelompok konseling tidak intensif lebih besar dibandingkan kelompok konseling intensif. Hal ini dapat ditinjau dari aktivitas fisik yang dilakukan kelompok konseling tidak intensif lebih tinggi dibanding kelompok konseling intensif. Penelitian membuktikan bahwa perubahan gaya hidup, salah satunya peningkatan aktivitas fisik, mampu menurunkan kadar IL-18 hingga 25-50\%. ${ }^{30}$ Aktivitas fisik dapat mengurangi inflamasi dengan memperbaiki fungsi endotel. Pengaktifan sel endotel tersebut dapat meningkatkan produksi sitokin proinflamasi, seperti interleukin 18, dan molekul adhesi yang menginduksi terjadinya inflamasi. Aktivitas fisik mengurangi tanda inflamasi terkait dengan disfungsi endotel. ${ }^{31}$

\section{SIMPULAN}

Konseling terbukti memodifikasi gaya hidup berupa peningkatan kualitas diet, aktivitas fisik, dan penurunan kadar IL-18 pada remaja obesitas dengan sindrom metabolik. Namun konseling modifikasi gaya hidup tidak terbukti meningkatkan asupan serat dan menurunkan kadar glukosa darah puasa. Konseling modifikasi gaya hidup yang dilakukan secara intensif selama dua bulan terbukti lebih meningkatkan kualitas diet dibandingkan konseling yang dilakukan secara tidak intensif. Namun, tidak terbukti bahwa konseling secara intensif lebih meningkatkan aktivitas fisik dan lebih menurunkan kadar IL-18.

\section{SARAN}

Frekuensi konseling sebaiknya diberikan dalam jumlah yang sama pada kelompok subjek yang ingin diintervensi. Konseling juga sebaiknya diberikan dalam waktu yang lebih lama dan pertemuan yang lebih intensif, yaitu lebih dari dua bulan dengan pertemuan satu minggu sekali. Melalui konseling ini diharapkan para konselor gizi dapat membantu klien untuk meningkatkan kualitas diet, aktivitas fisik, dan asupan serat, serta menurunkan kadar glukosa darah puasa dan kadar interleukin 18 .

\section{DAFTAR PUSTAKA}

1. Teng KT, Chang CY, Chang LF, Nesaretnam K. Modulation of Obesity-Induced Inflammation by 
Dietary Fats: Mechanisms and Clinical Evidence. Nutrition Journal 2014; 13 (12): 1.

2. Ogden CL, Carroll MD, Kit BK, Flegal KM. Prevalence of Childhood and Adult Obesity in The United States, 2011-2012. JAMA 2014; 311 (8): 4.

3. Badan Penelitian dan Pengembangan Kesehatan, Kementrian Kesehatan RI. Riset Kesehatan Dasar, RISKESDAS 2013. Indonesia: Kementrian Kesehatan RI; 2013: 222-223.

4. Rodriques RA. Perbedaan Kadar Interleukin (IL)-18 antara Kelompok Pra-Sindrom Metabolik dan Sindrom Metabolik Pada Remaja Obesitas. Semarang: Universitas Diponegoro 2014.

5. Park J, Hilmers DC, Mendoza JA, Stuff JE, Liu Y, Nicklas TA. Prevalence of Metabolic Syndrome and Obesity in Adolescent Aged 12-19 Years: Comparison between the United States and Korea. Journal Korean Medicine Science 2010; 25: 75

6. Engelsen CD, Koekkoek PS, Gorter KJ, Donk MVD, Salome PL, dan Rutten GE. High-Sensitivity CReactive Protein to Detect Metabolic Syndrome in a Centrally Obese Population: A Cross-Sectional Analysis. BioMed Central: Cardiovascular Diabetology 2012; 11 (25):1-2.

7. Bruun JM, Stallknecht B, Helge JW, dan Richelsen B. Interleukin-18 in Plasma and Adipose Tissue: Effects of Obesity, Insulin Resistance, and Weight Loss. European Journal of Endocrinology 2007; 157: 465.

8. American Diabetes Association. Diagnosis and Classification of Diabetes Mellitus. Diabetes Care 2010: 33 (1); 5 .

9. Troseid M, Seljeflot I, Arnesen H. The Role of Interleukin-18 in The Metabolic Syndrome. Cardiovascular Diabetology: BioMed Central 2010; 9 (11): 1-2.

10. Bose KSC, Gupta SK, Vyas P. Adypocytokine Levels in Genetically High Risk for Type 2 Diabetes in The Indian Population: A Cross-Sectional Study. Experimental Diabetes Research 2012; 4.

11. Putri PA. Perbedaan Asupan Energi, Lemak, Serat, dan Aktivitas Fisik pada Anak Obesitas dan Non Obesitas Usia 3-5 Tahun. Semarang: Universitas Diponegoro 2013.

12. Santawati FV. Hubungan Asupan Serat dengan Beberapa Faktor Risiko Penyakit Kardiovaskuler. Semarang: Universitas Diponegoro 2010.

13. Esposito K, Nappo F, Giugliano F, Palo CD, Ciotola M, Barbieri M, et al. Meal Modulation of Circulating Interleukin 18 and Adiponectin Concentrations in Healthy Subjects and in Patients with Type 2 Diabetes Mellitus. American Journal Clinical Nutrition 2003: 78; 1135-1136.

14. Heijden GJVD, Wang ZJ, Chu ZD, Sauer PJJ, Haymond MW, Rodriguez LM, et al. A 12-Weeks Aerobic Exercise Program Reduces Hepatic Fat Accumulation and Insulin Resistance in Obese, Hispanic Adolescents. Obesity Journal 2010; 18 (02): 384.
15. Anam MS. Pengaruh Intervensi Diet dan Olahraga terhadap Indeks Massa Tubuh, Kesegaran Jasmani, hsCRP dan Profil Lipid pada Anak Obesitas. Semarang: Universitas Diponegoro 2010.

16. Belalcazar LM, Reboussin DM, Haffner SM, Hoogeveen RC, Kriska AM, Schwenke DC, et al. A 1-Year Lifestyle Intervention for Weight Loss in Individuals with Type 2 Diabetes Reduces High CReactive Protein Levels and Identifies Metabolic Predictors of Change. Diabetes Care Journal 2010; 33 (11): 2297

17. Widianti N. Hubungan antara Body Image dan Perilaku Makan dengan Status Gizi Remaja Putri di SMA Theresiana Semarang. Universitas Diponegoro 2012: 6

18. Sada M, Hadju V, Dachlan DM. Hubungan Body Image, Pengetahuan Gizi Seimbang, dan Aktivitas Fisik terhadap Status Gizi Mahasiswa Politeknik Kesehatan Jayapura. Universitas Hasanuddin 2012: 45 .

19. Muslihah N, Winarsih S, Soemardini, Zakari AS, Zainudiin. Kualitas Diet dan Hubungannya dengan Pengetahuan Gizi, Status Sosial Ekonomi, dan Status Gizi. Universitas Brawijaya 2013; 8 (1): 72.

20. Hestuningtyas TR. Pengaruh Konseling Gizi terhadap Pengetahuan, Sikap, Praktik Ibu dalam Pemberian Makan Anak, dan Asupan Zat Gizi Anak Stunting Usia 1-2 Tahun di Kecamatan Semarang Timur. Universitas Diponegoro 2013:16.

21. Aurora RG, Sinambela A, Noviyanti CH. Peran Konseling Berkelanjutan pada Penanganan Pasien Hiperkolesterolemia. Journal Indonesia Medical Association 2012: 62 (5); 200.

22. Pratamaningtyas SP. Indeks Massa Tubuh dan Tingkat Kebugaran Jasmani pada Remaja Usia 13-15 Tahun di Kecamatan Rongkop Kabupaten Gunung Kidul dan di Kota Yogyakarta. Yogyakarta: Universitas Gadjah Mada; 2014.

23. Rahayuningtiyas F. Hubungan antara Asupan Serat dan Faktor Lainnya dengan Statis Gizi Lebih pada Siswa SMPN 115 Jakarta Selatan Tahun 2012. Depok: Universitas Indonesia 2012; 79.

24. Gallaway MS, Jago R, Baranowski T, Baranowski JC, Diamond PM. Psychosocial and Demographic Predictors of Fruit, Juice and Vegetable Consumption among 11-14-yeaar-old Boy Scouts. Public Health Nutrition 2007: 10 (12); 1512.

25. Farisa S. Hubungan SIkap, Pengetahuan, Ketersediaan dan Keterpaparan Media Massa dengan Konsumsi Buah dan Sayur pada Siswa SMPN 8 Depok Tahun 2012. Depok: Universitas Indonesia 2012; 3-4.

26. Noia JD, Contento IR. Fruit and Vegetable Availability Enables Adolescent Consumption that Exceeds National Average. Elsevier: Nutrition Research 2010: 30 (6); 6-7.

27. Oluwayemi IO, Brink SJ, Oyenusi EE, Oduwole OA, Oluwayemi MA. Fasting Blood Glucose Profile among Secondary School Adolescent in Adi-Ekiti, 
Nigeria. Journal of Nutrition and Metabolism 2015; 3.

28. Hajer GR, Haeften TWV, Visseren FLJ. Adipose Tissue Dysfunction in Obesity, Diabetes, and Vascular Diseases. European Heart Journal 2008: 29; 2959-2960.

29. Alam RAC, Jafar N, Virani D. Hubungan Skor Kualitas Diet dengan Komponen Sindrom Metabolik pada Pasien Rawat Jalan di RSP. Universitas Hasanuddin dan RS. Ibnu Sina Makassar Tahun 2013. Makassar: Universitas Hasanuddin 2013; 13.

30. Leick L, Lindeegard B, Stensvold D, Ploomgard P, Saltin B, Pileegard H. Adipose Tissue Interleukin-18 mRNA and Plasma Interleukin-18: Effect of Obesity and Exercise. Obesity 2007: 15 (2); 362.

31. Kasapis C, Thompson PD. The Effect of Physical Activity on Serum C-Reactive Protein and Inflmmatory Markers. Journal of The American College of Cardiology 2005: 45 (10); 1567 